\title{
Application Of Student Teams-Achievement Divisions (Stad) On Material Of Land Degradation And Impact on Humans
}

\author{
Deasy Arisanty \\ Department of Geography Education \\ Faculty of Teaching and Education \\ Universitas Lambung Mangkurat \\ Banjarmasin, Indonesia \\ deasyarisanty@unlam.ac.id
}

\author{
Nevy Farista Aristin, Misna \\ Department of Geography Education \\ Faculty of Teaching and Education Science \\ Banjarmasin, Indonesia \\ Universitas Lambung Mangkurat
}

\begin{abstract}
The students' geography learning result was influenced by various external factors. One of external factors was teacher learning model. The objective of research is to analyze the using of STAD learning model to improve student learning outcomes on the material of degradation of land and its impact for human life on Class X, SMA Negeri 9 Banjarmasin. The study was used quasi experimental experimental research. The population of research was student at SMA Negeri 9 Banjarmasin. Samples of research is class X-5 as the experimental class with the number of respondent is 36 students and class $\mathrm{X}-4$ as the control class with the number of respondent is 35 students. The data analysis technique was gain score calculation and $t$ test. The result of this research was the implementation of STAD learning model. The result of research showed that gain score of experimental class was $t_{\text {count }}=4.82227$ and $t_{\text {table }}=1.690924$. Control class was $t_{\text {count }}=47.6248$ and $t_{\text {table }}=$ 1.69236. The result of $t$ test of experiment class and control class is $0.000<0.05$ then $\mathrm{Ho}$ is rejected and Ha accepted. STAD could be improved the students' geography learning outcomes on the material of land degradation and its impact for human life.
\end{abstract}

Keywords—STAD, Learning outcomes, geography

\section{INTRODUCTION}

Cooperative learning is systematic model to create the effective learning, academic content, social skill integrating, problem solving, learning material understanding [1-2]. Cooperative learning is focused for student. One of cooperative learning is student team achievement division (STAD).

STAD model is developed by Slavin and Hopkin. STAD model uses the approach concept of simple learning, that model may help teachers to explain the learning material for their student. STAD model creates the student creativity, inovative, active, high motivation, and high understanding [3].

The strengthness of STAD model according to Slavin consist of 1) increasing the student knowledge through interaction others people, 2) increasing student motivation through the evaluation of teaching and learning processes [4]. The weakness of STAD model consists of 1) low contribution from low achievement student, 2) high roles from high achievement student [5].

STAD model is effectively for increasing the student learning outcomes [6-7]. STAD model also can increase the student social skill student. STAD model also has the impact for teaching and learning activity [6].

STAD has been used various disciplines to improve learning outcomes and student activities, such as social studies, mathematics, and sport studies. STAD models can increase an active and interactive in the teaching and learning on social studies [6]. STAD is also can increase the student achievement on mathematics [7]. STAD is also can increase the student activity in study of sport [8].

Geography is a study about the natural phenomena and its relation for human life. The geography phenomena need to explain using the demonstration. STAD models are needed to present the material about land degradation and impact for human life. Based on the background, the objectives of research is to analyze the using of STAD learning model to improve student learning outcomes on the material of degradation of land and its impact for human life on Class X, SMA Negeri 9 Banjarmasin.

\section{METHOD}

The research uses the quasi-experimental research. Quasi experiment consists of treatment, impact measurement, and experimental units. The function of control variable is not used fully for external variable control [9]. Research uses the pre-test and post-test, that the tests are used to get the learning outcome both in experiment class and control class. Samples of research is class X-5 as the experimental class with the number of respondent is 36 students and class X-4 as the control class with the number of respondent is 35 students.

The instrument of research is multiple choice questions. Number of questions is about 20 questions. Research uses SPSS 16. Validity and reliability is used as instrumental testing. Validity is presented in equation 1 and reliability is presented in equation 2 [10]. 


$$
\begin{gathered}
r_{x 1}=\frac{n\left(\sum X Y\right)-\left(\sum x\right)\left(\sum Y\right)}{\sqrt{\left[n \sum X^{2}-\left(\sum X\right)^{2}\right]\left(n \sum Y^{2}-\left(\sum Y\right)^{2}\right]}}(1) \\
K R_{20}=\frac{n}{n-1}\left[\frac{s_{t}^{2}-\sum p q}{s_{t}^{2}}\right] \text { (2) }
\end{gathered}
$$

To understand the different of learning outcome between control class and experiment class uses independent sample ttest. Data is also analyzed using Gain Score of student learning outcomes derived from the pretest and posttest. The analysis uses SPSS 16. Independent t-test is presented in equation 3 [10].

$$
t=\frac{\sum d_{i}}{\sqrt{\frac{N d_{i}^{2}-\left(\sum d_{i}\right)^{2}}{N-1}}}(3)
$$

\section{RESULT AND DISCUSSION}

Gain score calculation function is used to determine a significant difference between the values obtained pretest and posttest students. Score Gain calculation results presented in

\begin{tabular}{|c|c|c|c|c|}
\hline \multirow[t]{2}{*}{ No } & \multirow[t]{2}{*}{ Class } & \multirow{2}{*}{$\begin{array}{l}\text { The number of } \\
\text { students }\end{array}$} & \multicolumn{2}{|c|}{ Difference (Gain) } \\
\hline & & & $\mathrm{t}_{\text {count }}$ & $\mathrm{t}_{\text {table }}$ \\
\hline 1 & $\begin{array}{c}\text { X5 (experiment } \\
\text { class) }\end{array}$ & 36 & 34.9450 & 1.690924 \\
\hline 2 & $\begin{array}{c}\text { X4 (control } \\
\text { class) }\end{array}$ & 35 & 47.6248 & 1.692360 \\
\hline
\end{tabular}
Table 1 below.

TABLE 1. DIFFERENCES BETWEEN PRE-TEST AND POST-TEST

Source: Data Analysis (2017)

The significant value is difference between pre-test and post-test value, both in control group class and experimental group class. This can be seen in both classes tcount greater than ttable. In the control group got the $t_{\text {count }}(47.6248)>t$ table (1.690924) and the experimental class got the $t_{\text {count }}$ (34.9450)> $t_{\text {table }}(1.692360)$.

Based on result of research, pre-test is used as to understand the capability of student. Post-test uses to understand the student understanding about the learning

\begin{tabular}{|c|c|c|c|c|}
\hline \multirow[t]{2}{*}{ No } & \multirow[t]{2}{*}{ Class } & \multirow{2}{*}{$\begin{array}{c}\text { The number of } \\
\text { student }\end{array}$} & \multicolumn{2}{|c|}{ Average score } \\
\hline & & & Pre-test & Post-test \\
\hline 1 & $\begin{array}{c}\mathrm{X} 5 \\
\text { (experiment } \\
\text { class) }\end{array}$ & 36 & 35.28 & 74.58 \\
\hline 2 & $\begin{array}{l}\mathrm{X} 4 \text { (control } \\
\text { class) }\end{array}$ & 35 & 38.85 & 62.28 \\
\hline
\end{tabular}
material, about the land degradation and impact for human life.

Source: Primary Data analysis (2016)

Pre-test mean on X5 is 35.28 and post-test on X5 is 74.58 . Both pre-test and post-test in X 4 are 38.85 and 62.28. Posttest score of X5 class as experimental class is higher than X4 as a control class. The research shows that STAD model can increase the student learning outcome for material about land degradation and impact for human life.
Result of calculation of normality test from preliminary data of X5 and X4 shows that sample data of X5 and X4 has normal distribution, due to significant value of one sample $>0,05$. Ho is rejected, and Ha is accepted.

Hypothesis testing is done by using the Independent Sample t-Test in SPSS 16.0 for Windows. The test result is Sig (2-tailed) $\leq 0.05(0.000 \leq \alpha 0.05)$. The result of research is $\mathrm{H} 0$ rejected and $\mathrm{Ha}$ accepted, which means that significant differences of learning outcome between STAD and conventional learning. The results of research indicate that STAD can improve geography learning outcomes on material land degradation and impact for human life.

STAD is learning model that emphasize for student activity. STAD can enrich the student academic performance [11, [12]. STAD models can increase the student learning outcomes [7], [13]. STAD models can use for improving the academic achievement level of participating students, and for promoting the positive attitudes of students [14].

Some suggest about the STAD model follows:

a. STAD learning model is very good applied to the learning material of geography because it can improve student learning outcomes, motivation, spirit of learning, and tolerance of fellow peers.

b. The school can facilitate suggestions and infrastructure to support the learning process and hope that a teacher can use various learning models to make learning more meaningful and fun.

Improving student learning outcomes, requiring the expertise of a teacher, the school hopes to support the participation of a teacher in a learning training in various fields.

\section{CONCLUSION}

STAD is more effective to improve the student learning outcome in material of land degradation and impact for human life. Pre-test mean on X5 is 35.28 and post-test on X5 is 74.58 . Pre-test and post-test in X 4 are 38.85 and 62.28. Post-test score of X5 class as experimental class is higher than X4 as a control class.

\section{REFERENCES}

[1] Sumarmi, Model-Model Pembelajaran Geografi, Malang: Aditya media Publshing, 2012

[2] S. Eveline, Nara Hartini, Teori belajar dan pembelajaran, Jakarta: Ghalia Indonesia, 2014

[3] A. Noeruddin, "Implementasi Model Pembelajaran Kooperatif Tipe STAD disertai Pemberian Umpan Balik Berbasis Contextual Teaching and Learning (CTL) untuk Meningkatkan Hasil Belajar Mahasiswa pada Mata Kuliah Kalkulus Peubah Banyak IKIP PGRI Bojonegoro", Media Prestasi Jurnal Ilmiah STKIP PGRI Ngawi Vol.13 No. 1, 2014, $31-41$

[4] Zulkarnain, "The Effect of Stad Type Cooperative Learning Initiated by Story Questions toward the Ability to Complete Story Questions in Math of Class viii Students of Junior High School (SMPN 1 and MTSN) in Pangean District, Kuantan Singingi Regency", Mediterranean Journal of Social Sciences, Vol 6 No 3 S1, 2015

[5] Gusniar, Penerapan Model Pembelajaran Kooperatif Tipe Student Teams Achievment Division (STAD) Dalam Meningkatkan Hasil Belajar Siswa Pada Mata Pelajaran IPS Kelas IV SDN No. 2 Ogoamas II, 2014 
[6] Munawaroh, "The Effect of Type Stad Cooperative Learning Model, the Way of Learning, And Learning Motivation toward Enterpreneurial Attitudes (A case Study in SMK N I Jombang)", IOSR Journal of Research \& Method in Education (IOSR-JRME), Volume 3, Issue 5, 2013, pp 38-44

[7] I. Novianti, "Experimentation Cooperative Learning Student Team Achievement Division (STAD) Type Viewed From Learning Motivation. Asian Journal of Education and e-Learning", Volume 01Issue 05,2013

[8] K.A. Samudra, "Model Kooperatif STAD untuk Meningkatkan Aktivitas dan Hasil Belajar Passing Voli”, Jurnal Pendidikan Jasmani, Olahraga dan Kesehatan, volume 1 No 2, 2013.

[9] Cook and Campbell, Quasi and Experimentation: Design and Analyze Issues for Field Setting, Houghton Mifflin Co, 1979

[10] E. Riadi, Statistika Penelitian (Analisis Manual dan IBM SPSS),Yogyakarta: Andi Offset, 2016.
[11] D T. G. Narzoles, "Student Team Achievement Division (STAD):Its Effect on The Academic Performance of EFL Learners", American Research Journal of English and Literature, Volume 1, Issue 4, 2015

[12] A. I. Gambar1, and M. O. Yusuf, "Effectiveness of Computer-Assisted Stad Cooperative Learning Strategy on Physics Problem Solving, Achievement and Retention", Malaysian Online Journal of Educational Technology, Volume 3, Issue 3, 2015.

[13] D. R. Slagle, The Use of the Cooperative Learning Strategy STAD to Promote Academic Achievement, Thesis of Master of Arts in Education Program of Defiance College In a High School Social Studies Class, 2009.

[14] Van Dat Tran, "Effects of Student Teams Achievement Division (STAD) on Academic. Achievement, and Attitudes of Grade 9th Secondary School Students towards Mathematics", International Journal of Sciences, Volume 2, 2013 